\title{
Numerical Study of the Seismic Efficiency of Buckling-Restrained Braces for Near and Far-Fault Inputs
}

\author{
G.L. Palazzo ${ }^{1}$, P. Martín ${ }^{1}$, F. Calderón ${ }^{1}$, V. Roldán ${ }^{1}$ and F. López-Almansa ${ }^{2, *}$ \\ ${ }^{I}$ National Technological University, Mendoza Faculty, Ceredetec, Argentina \\ ${ }^{2}$ Technical University of Catalonia, Architecture Structures Department, Barcelona, Spain
}

\begin{abstract}
Buckling-restrained braces are commonly installed in building structures as concentric diagonal or chevron braces to protect the main construction from seismic actions. These elements have shown repeatedly their usefulness for reducing the seismic response, both from theoretical and experimental studies; and a number of practical applications have been reported. However, seismic records with near-fault effects possess special characteristics that might impair the performance of these devices, similarly as what occurs in base isolation; about energy issues, in such records (containing strong velocity pulses) the energy is delivered in a short time interval, thus being difficult to be absorbed. This work presents a numerical study regarding the performance of buckling-restrained braces under three types of seismic records: cortical far-field, subductive far-field and near-field (i.e. containing velocity pulses). The study is carried out on a symmetric 4-story steel moment-resisting unbraced frame that was tested at the E-defense laboratory, Japan; the dynamic response of such unbraced bare frame is numerically simulated, obtaining a satisfactory agreement. The same numerical model is used to describe the 2-D dynamic behavior of the steel frame equipped with buckling-restrained braces. The inputs are three series of ten ground motion records; each of these series belongs to one of the three aforementioned types. The average responses for each of the three types of inputs are compared; the obtained results show that the buckling-restrained braces are able to reduce the dynamic response of the frame and that no significant differences can be observed among the efficiency for far-fault and near- fault records.
\end{abstract}

Keywords: Buckling-restrained braces, near-fault records, seismic efficiency, steel building structures, velocity pulses.

\section{INTRODUCTION}

Energy dissipators are intended for seismic protection of buildings and other constructions. They take up most of the input energy; as a result, the main structure remains protected, even for severe ground motions $[1,2]$. There have been numerous realizations [3]. Hysteretic devices (e.g. based on plastification of metals) are efficient, while keeping simplicity, economy and reliability. Buckling-restrained braces are one of the most common hysteretic dissipators, having been mostly considered for buildings $[4,5]$. These elements have slender steel core bracing rods; typically are used either as diagonal or chevron concentric braces Figs. (1a) and (1b), respectively). Under severe seismic inputs, tensile and compressive axial stresses exceed the steel yielding point; core buckling is prevented by encircling it with a squattest encasing (see Fig. (1c)). That casing is either steelbased $[6,7]$ or contains steel-coated mortar Fig. (1d). Undesirable shear stress transfer between steel core and casing is prevented by a sliding interface.

Compared to other hysteretic devices, bucklingrestrained braces hold significant advantages:

- They are a full bracing system, instead of being smaller members requiring braces to connect to the main frame.

*Address correspondence to this author at the Technical University of Catalonia, Architecture Structures Department, Barcelona, Spain;

Tel: +34-93-4016316, +34-606807733; Fax: +34-93-4016096;

E-mail: francesc.lopez-almansa@upc.edu
- The dissipative segment of the core can encompass nearly the whole brace-length; therefore, axial strain is low and plastic excursions are rather moderate. Moreover, plastification is uniform along the core. For that reasons, fatigue resistance may be high.

- Worldwide experience is relevant. Experiments have been conducted [7, 10-16] and there are applications in Japan [6], Taiwan [7], Canada [17] and the United States [10], among other countries. Draft codes have been proposed [18-20] and many references about design guidelines have been published [12, 13, 21-24]. For instance, code [25] deals with buckling-restrained braces.

- Ratio between the absorbed energy and the appended material is high [26], this indicates satisfactory performance.

Despite buckling-restrained braces have been deeply analyzed, there are still some open questions. Among them, the ability of these devices to reduce the seismic response of low-rise buildings compared to conventional concentric bracing [27] or, mainly, their performance under near-fault records. Near-fault seismic records possess special characteristics that might impair the performance of these devices (as occurs with base isolation) since they can generate a relevant residual drift displacement [28] and, about energy issues, the energy is delivered in a short time interval, thus being difficult to be absorbed. The study [29] addresses this issue, concluding that the performance of the buckling-restrained 

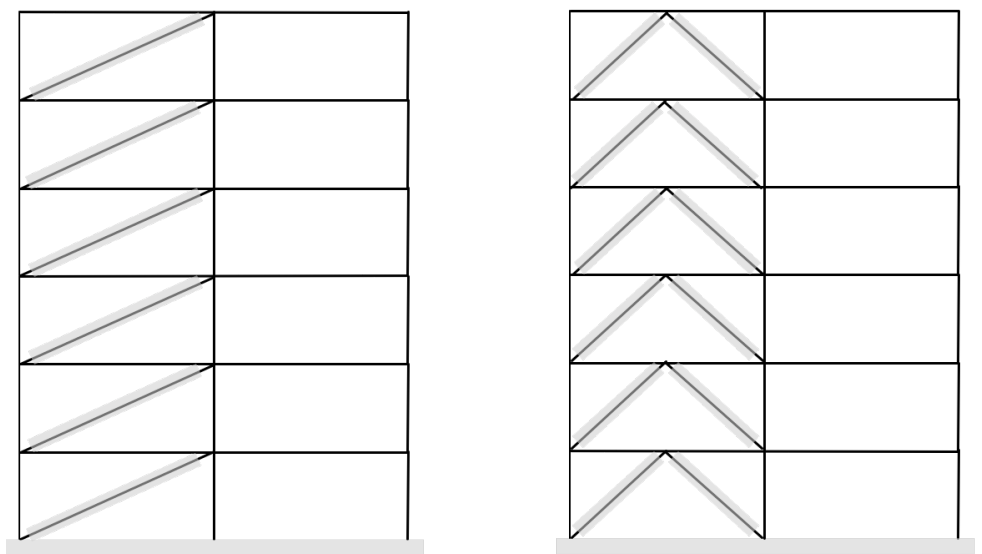

(a) Building frames incorporating buckling-restrained braces

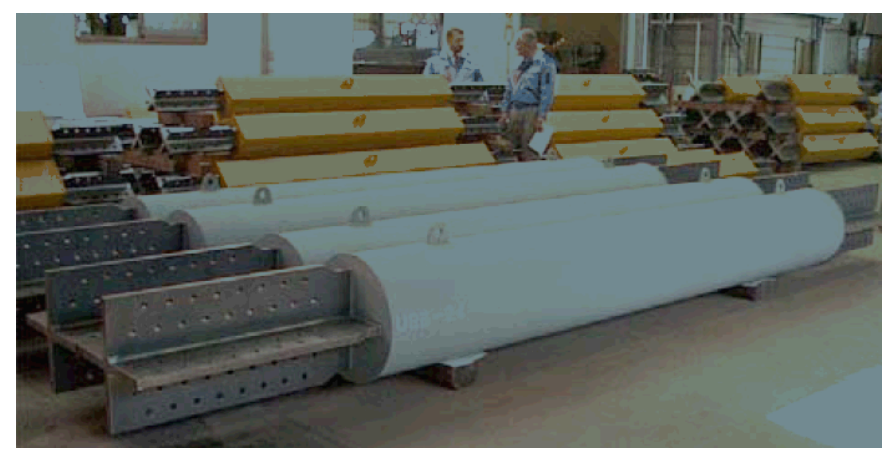

(c) Buckling-restrained braces with circular and rectangular cross-sections [9]

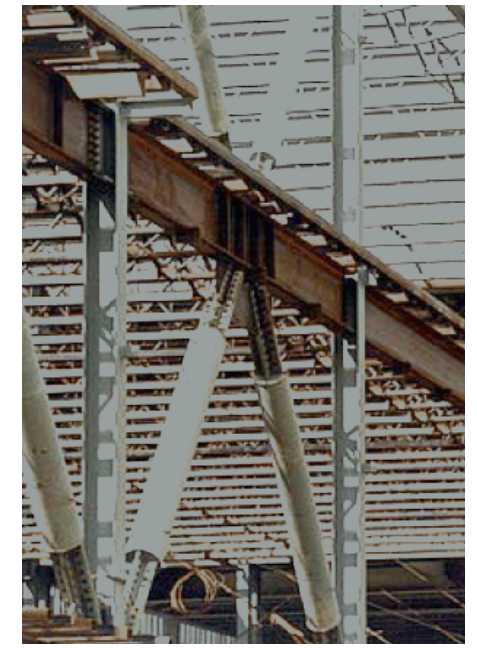

(b) Protected steel building frame [8]

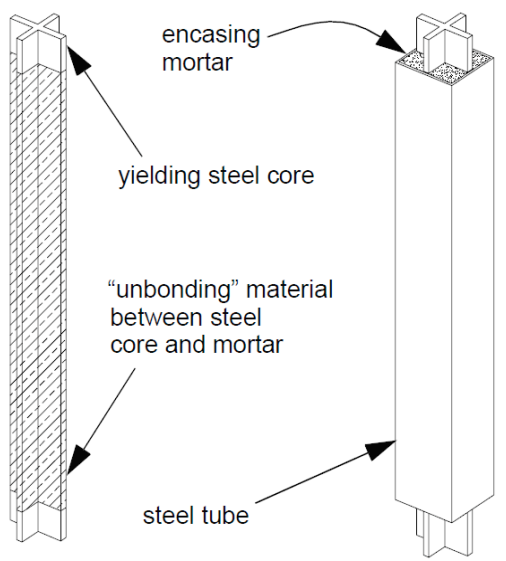

(d) Detail of a device [9]

Fig. (1). Buckling-restrained braces.

braces under near-fault inputs is acceptable but there are important permanent story drifts. This paper presents a numerical study regarding the performance of bucklingrestrained braces under three types of seismic records: cortical far-fault, subductive far-fault and near- fault. The study is carried out on a symmetric 4-story steel moment-resisting frame that was dynamically tested to collapse in 2007 at the shaking table of the E-defense laboratory [30-32]; the experiments consisted of applying a 3-D scaled version of a near-fault motion recorded during the Kobe earthquake $(16 / 01 / 1995)$ to the frame. The dynamic response of such frame is numerically simulated in this work; since the agreement is satisfactory, the results derived from such model are reliable. This numerical model is used to describe the 2-D dynamic behavior of the steel frame equipped with buckling-restrained braces under thirty seismic accelerograms. Such inputs are composed of three series of ten ground motion records each: ten are cortical far-fault, other ten are subductive far-fault and the remaining ten are nearfault.

This research is a part of a wider initiative aiming to foster, in developing areas, the bulk use of patent-free bucklingrestrained braces. Overall strategy consists of: (1) designing, producing and testing (individually) a number of shortlength devices (approximately $400 \mathrm{~mm}$ long) [33, 34], (2) designing, producing and testing (also individually) larger elements (approximately $3000 \mathrm{~mm}$ long) [35], (3) developing basic numerical models of the structural behavior of buckling-restrained braces [35], (4) deriving more sophisticated models [36, 37], (5) designing, producing and testing (on subassemblies) full-scale devices and (6) conducting a parametric study on their performance. First four objectives are accomplished while last two are in progress; this work deals principally with sixth target.

\section{CONSIDERED STEEL FRAME}

\subsection{Tested Bare Frame}

The tested steel frame is described in the works [30-32, 38]; only a brief explanation is presented here. The specimen consists of a two-bay four-story moment-resisting steel frame without any structural bracing; Fig. (2) displays one sketch and one picture. The two span-lengths in the main direction are $5 \mathrm{~m}$ while in the transversal direction the spanlength is $6 \mathrm{~m}$; the first floor is $3.875 \mathrm{~m}$ high and the height of the upper floors is $3.5 \mathrm{~m}$. The first floor columns are rigidly connected to $1.5 \mathrm{~m}$ high supporting concrete blocks; in their turn, the blocks are clamped to the shaking table. The beamcolumn connections are basically rigid and were detailed according to the practice developed following the 1995 Hyogoken-Nanbu earthquake $(16 / 01 / 1995)$ to force the formation of plastic hinges out of the joints. However, tubular 


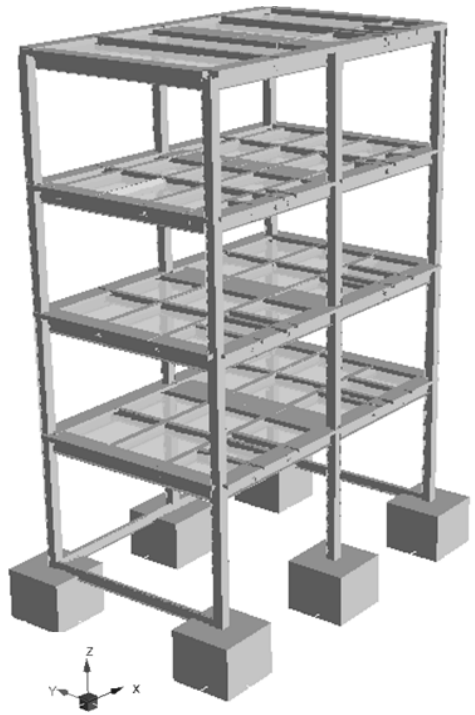

(a) Sketch of the unbraced frame

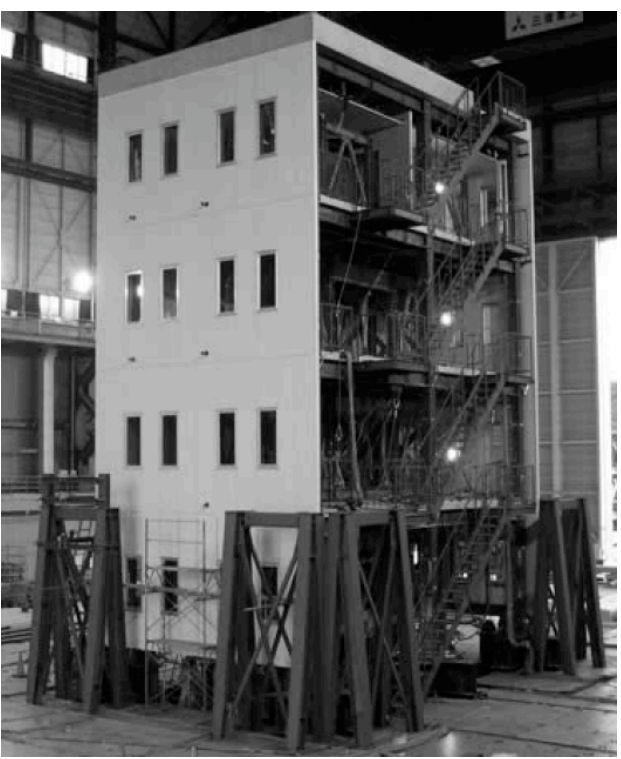

(b) Picture of the frame [38]

Fig. (2). Tested steel frame.

columns with high width-to-thickness ratio $(\approx 30)$ were used and local buckling developed in the first-story column, it reduced the bending strength of the columns. This reduced bending strength, combined with strain hardening of the panel zone at the beam level, led to the first-story collapse mechanism that was observed $[39,40]$.

\subsection{Description of the E-defense Experiments}

The experiments consisted of shaking the specimen frame with three 3-D scaled versions of a ground motion recorded in Takatori during Kobe earthquake (16/01/1995). The first, second and third inputs were scaled at $40 \%, 60 \%$ and $100 \%$, respectively. The $40 \%$ input was aimed to generate only elastic deformations in the frame, the $60 \%$ input produced inelastic deformations and almost collapsed the frame, and the $100 \%$ input caused the collapse of the frame.

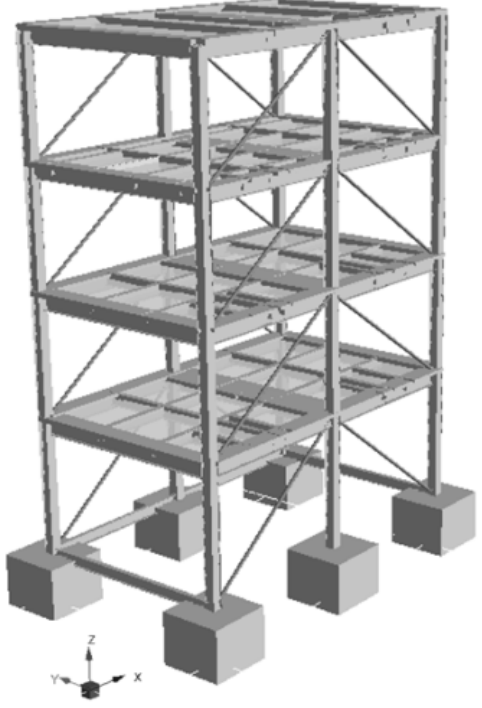

Fig. (3). Tested steel frame incorporating buckling-restrained braces.

\subsection{Considered Buckling-Restrained Braces}

As discussed before, this study aims to assess the ability of buckling-restrained braces to reduce the dynamic response of building frames under different types of seismic inputs. For this purpose, concentric diagonal braces are incorporated to the front and rear longitudinal façades, as depicted in Fig. (3). Since there are only inputs in the longitudinal direction and the frame is symmetric, no braces in the transverse direction have been installed.

The design parameters of the buckling-restrained braces are the steel yielding point and the length and the cross section of the yielding portion of the steel core. In all the cases the steel yielding point is $240 \mathrm{MPa}$ and the length of the yielding segment of the core is assumed to be equal to the total length of the braces. In practice, this brace geometry cannot be achieved since the core must be interrupted at some distance from the brace ends to allow for brace connections; however, this assumption has no relevant effect on the conclusions of this study. Therefore, the only remaining design variable is the sectional area of the core. The cross section of the steel core is circular and its diameter is chosen by two different approaches: the design methodology proposed in [41] and an empirical criterion that consists basically of selecting the diameter proportionally to the inter-story drift. The two arising solutions are termed along this paper BRB1 and BRB2, respectively; both design approaches are described next.

- BPR1. The diameters of the braces are iteratively selected such as their yield displacements are equal to a given percentage [27] of the displacements that those members would experience under the equivalent static forces; the chosen percentages are 38\%, 21\%, 15\% and $12 \%$ for the braces in the first, second, third and fourth floor, respectively. The equivalent forces are determined from the Argentinean design code [42] for normal soil conditions and seismic zone 4 ( $0.35 \mathrm{~g}$ design ground acceleration). Then, performance of the braces is verified 
Table 1. Diameters ( $\mathrm{mm})$ of the sets of buckling-restrained braces BRB1 and BRB2.

\begin{tabular}{|c|c|c|c|c|}
\hline \multirow{2}{*}{ Set of Braces } & \multicolumn{5}{|c|}{ Floor Number } \\
\cline { 2 - 5 } & $\mathbf{1}$ & $\mathbf{2}$ & $\mathbf{3}$ & $\mathbf{4}$ \\
\hline \hline BRB1 & 30 & 30 & 20 & 10 \\
\hline BRB2 & 25 & 25 & 20 & 20 \\
\hline
\end{tabular}

from nonlinear time-history analyses; prescribed performance requirements are stated.

- BPR2. The design criterion consists of selecting the diameters of the braces as to obtain, for an equivalent seismic static analysis, uniform drift along the height of the building; such common value is chosen as $1.9 \%$. The considered equivalent static forces are determined as for the BPR1 set. This operation is carried out iteratively until reaching a sufficient degree of uniformity for the drift.

Table 1 sisplays the diameters for both solutions. Table 1 shows that in the BRB1 set the variation of strength along the height of the building is more intense than in the BRB2 set.

\section{NUMERICAL MODELING OF THE STEEL FRAME}

\subsection{Numerical Model of the Steel Frame with Buckling- Restrained Braces}

This subsection describes the structural modeling of the steel frame and of the buckling-restrained braces. The analysis has been carried out by using the SeismoStruct software code [43]. The model consists of frame elements for columns and beams and of truss elements for buckling-restrained braces. The parameters used in the structural modeling of the frame were obtained from [38]. The contribution of the topping concrete layer to the stiffness of beams is accounted for by modeling every beam as a composite concrete-steel member; the effective width is determined according to [25]. The nonlinear behavior of the concrete is represented by a five-parameter constant-confinement concrete model [4446]; the confinement effect is described by an effective confinement stress which depends on the longitudinal and transverse reinforcement. Since this model can experience numerical instabilities under large displacements, the modifications suggested by [45] are considered; this new model can predict the strength and stiffness degradation under cyclic motion. The behavior of the steel of the frame members and of the braces is described by uniaxial bilinear constitutive laws with 5\%o (kinematic) strain hardening [38]; hardening rule is a linear function of plastic strain rate. Plastic behavior of columns and beams is represented by distributed 3-D fiber models by using the aforementioned constitutive laws; 100 fibers were considered in each transversal section. The diaphragm effect of the floor slabs is taken into account by imposing rigid links (constraints) among all the joints belonging to the same slab. The contribution of the non-structural elements (e.g. cladding and partitioning walls) is not accounted for. The second-order effects were included in the analysis. The damping effects are represented by the aforementioned nonlinear constitutive laws and by an additional non-hysteretic damping that is proportional to the tangent stiffness [47]; to avoid numerical instabilities, a viscous damping factor equal to $0.5 \%$ was also introduced in the analysis. The time integration was performed by the HilberHughes-Taylor algorithm [48].

\subsection{Numerical Simulation of the E-defense Experiments}

For the sake of verifying the accuracy and reliability of the model described in the previous subsection, this subsection describes the comparison among the experimental results [31] and the simulated ones. The considered input is not the Takatori ground motion record but the actual acceleration that shook the frame.

The fundamental periods in the longitudinal and transversal directions of the tested frame have been obtained by classical linear eigenvalue analysis. Table 2 displays the obtained results and the experimental ones. The agreement is satisfactory.

Table 2. Fundamental periods (s) of the bare tested frame.

\begin{tabular}{|c|c|c|}
\hline Direction & Numerical & Experimental \\
\hline \hline Longitudinal & 0.82 & 0.76 \\
\hline Transversal & 0.83 & 0.80 \\
\hline
\end{tabular}

Fig. (4) displays experimental and simulated results for each story under the input scaled at $60 \%$; for comparison purposes, the results obtained by [38] are also plotted. Figs. (4a-c) display the maximum values of the relative displacement, the drift angle (the ratio between the interstory drift and the story height) and the absolute acceleration, respectively. Fig. (4) shows a satisfactory fit; the accuracy of the considered model is adequate and is rather similar to the one from [38]. Similar conclusions can be derived for other relevant response magnitudes such as story shear or overturning moment. As well, the precision of the obtained results is analogous to the one of the winner of the blind contest [32].

\section{CONSIDERED SEISMIC INPUTS}

The numerical simulations aiming to assess the validity of the buckling-restrained braces consist of shaking the steel frame in its longitudinal direction ( $x$, see Fig. 3) with a number of recorded accelerograms. These records have been chosen to represent the types of seismic inputs that the structure might experience along its lifetime. The considered ground motion records were selected from [49]; the appendix A of that document proposes ground motion record sets for collapse assessment of building structures. Three groups of records were chosen: cortical far-field, subductive far-field and 


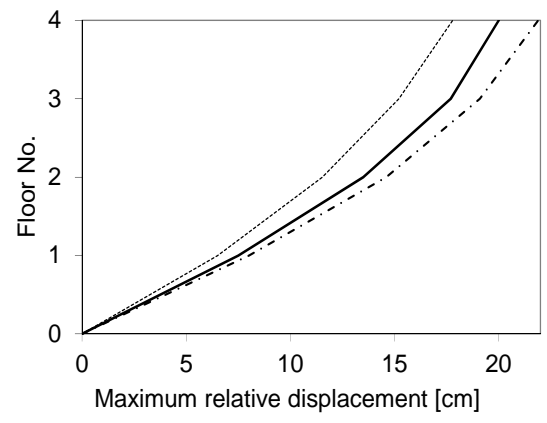

(a) Relative displacement

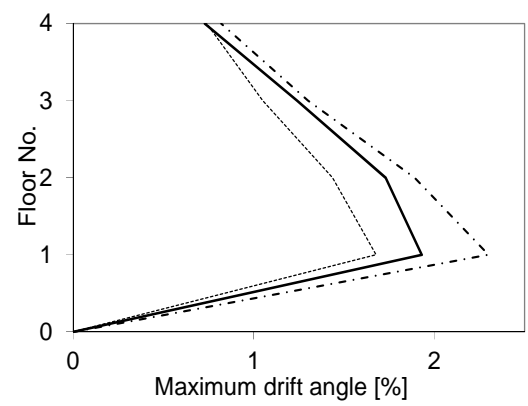

(b) Drift ratio

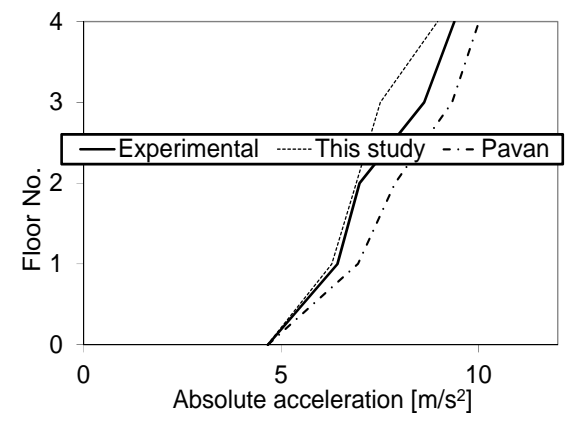

(c) Absolute acceleration

Fig. (4). Experimental and simulated results of the E-defense tests.

Table 3. Cortical zone. Far-field records.

\begin{tabular}{|c|c|c|c|c|c|c|c|c|c|}
\hline No. & Earthquake & Date & $\boldsymbol{M}_{\mathbf{w}}$ & Station & Comp. & PGA [g] & $\begin{array}{c}\text { PGV } \\
{[\mathbf{c m} / \mathbf{s}]}\end{array}$ & $\begin{array}{c}\text { Scale Factor } \\
\text { (DRS) }\end{array}$ & $\begin{array}{c}\text { Scale Factor } \\
\text { (MCE) }\end{array}$ \\
\hline \hline 1 & Cape Mendocino & $04 / 25 / 92$ & 7.0 & Rio Dell Overpass & $270^{\circ}$ & 0.385 & 43.8 & 2.11 & 3.17 \\
\hline 2 & Cape Mendocino & $04 / 25 / 92$ & 7.0 & Rio Dell Overpass & $360^{\circ}$ & 0.549 & 41.87 & 2.41 & 3.61 \\
\hline 3 & Chi Chi & $09 / 20 / 99$ & 7.6 & CHY 101 & N-S & 0.440 & 115.03 & 1.41 & 2.12 \\
\hline 4 & Chi Chi & $09 / 20 / 99$ & 7.6 & CHY 101 & E-W & 0.535 & 70.65 & 2.29 & 3.43 \\
\hline 5 & Kobe & $01 / 16 / 95$ & 6.9 & Nishi Akashi & $0^{\circ}$ & 0.509 & 37.28 & 3.44 & 5.16 \\
\hline 6 & Kobe & $01 / 16 / 95$ & 6.9 & Nishi Akashi & $90^{\circ}$ & 0.503 & 36.62 & 3.02 & 4.53 \\
\hline 7 & Northridge & $01 / 17 / 94$ & 6.7 & Canyon Country & $0^{\circ}$ & 0.410 & 42.97 & 3.21 & 4.82 \\
\hline 8 & Northridge & $01 / 17 / 94$ & 6.7 & Canyon Country & $270^{\circ}$ & 0.482 & 44.91 & 1.93 & 2.89 \\
\hline 9 & Duzce & $11 / 12 / 99$ & 7.1 & Bolu & $0^{\circ}$ & 0.728 & 56.44 & 1.85 & 2.78 \\
\hline 10 & Duzce & $11 / 12 / 99$ & 7.1 & Bolu & $90^{\circ}$ & 0.822 & 62.10 & 1.01 & 1.51 \\
\hline
\end{tabular}

near-field; each group contains ten accelerograms. The farand near-field records correspond to epicentral distances bigger and smaller than $10 \mathrm{~km}$, respectively. All the nearfault accelerograms contain strong velocity pulses. The considered accelerograms are individually scaled; the scaling factors are determined aiming that the resulting spectral ordinates fit those of the design spectra for the city of Santa Clarita (Los Angeles, California, site coordinates $34.3828^{\circ} \mathrm{N}$ $118.53463^{\circ} \mathrm{W}$ ) for soil $\mathrm{D}$, damping $5 \%$ and risk category I/II or III (http://geohazards.usgs.gov/designmaps/us/application. php). The scaling has been established for the fundamental period of the bare frame (Table 2) following the indications of [50]; that document states that in between periods $k_{1} T$ and $k_{2} T$ ( $k_{1}$ and $k_{2}$ are coefficients and $T$ is the fundamental period of the structure) the average of spectral ordinates should be bigger than the design spectral ordinates. Each record is scaled with two factors corresponding to the "Design Response Spectrum" (DRS) and to the "Maximum Considered Earthquake" (MCE) [50]; a constant ratio 1.5 among them has been assumed. Tables 3-5 present the most relevant information for the cortical far-field, the subductive far-field and the near-field group, respectively. Analogously, Fig. (5) displays the pseudo-acceleration response spectra of the scaled records; vertical lines indicated the interval that has been considered to adjust the individual spectra. For comparison purposes, the design spectra [50] corresponding to MCE or DRS levels are also plotted.

\section{NUMERICAL RESULTS OF THE STEEL FRAME WITH AND WITHOUT BUCKLING-RESTRAINED BRACES}

This section describes the simulation of the dynamic behavior of the tested steel frame equipped with bucklingrestrained braces (subsection 2.3) while undergoing the seismic inputs listed in section 4 (Tables 3-5). The numerical analyses are carried out by using the model described in section 3. For comparison purposes, the numerical results of the bare frame, e.g. without braces, are also plotted; along this section, the results for the bare frame are identified as "Bare" while those for both sets of braces are identified as "BRB1" and "BRB2", respectively (Table 1).

Prior to simulating the dynamic response to the selected inputs, a linear eigenvalue analysis has been performed to determine the modal parameters of the frame equipped with the buckling-restrained braces. The obtained fundamental periods in the $x$-direction are $0.523 \mathrm{~s}$ and $0.543 \mathrm{~s}$ for the sets of braces BRB1 and BRB2, respectively (Table 1). Comparison with the figures displayed in Table 2 indicates a significant stiffening effect of the braces.

Fig. (6) displays the average values (for each of the groups of records in Tables 3-5) of the maximum relative displacement of each floor and Fig. (7) shows similar plots about the maximum interstory drift. To report about the dispersion among the records, Fig. (8) displays the maximum 
Table 4. Subductive zone. Far-field records.

\begin{tabular}{|c|c|c|c|c|c|c|c|c|c|}
\hline No. & Earthquake & Date & $\boldsymbol{M}_{\mathbf{w}}$ & Station & Comp. & PGA [g] & $\begin{array}{c}\text { PGV [cm/s] } \\
\begin{array}{c}\text { Scale Factor } \\
\text { (DRS) }\end{array}\end{array} \begin{array}{c}\text { Scale Factor } \\
\text { (MCE) }\end{array}$ \\
\hline \hline 1 & Pisco (Perú) & $15 / 08 / 07$ & 8.0 & La Molina & E-W & 0.08 & 11.64 & 12.29 & 18.43 \\
\hline 2 & Pisco (Perú) & $15 / 08 / 07$ & 8.0 & La Molina & N-S & 0.07 & 159.3 & 14.85 & 22.28 \\
\hline 3 & Maule (Chile) & $08 / 04 / 10$ & 8.8 & Maule & Ch. 1 & 0.401 & 69.28 & 1.65 & 2.47 \\
\hline 4 & Maule (Chile) & $08 / 04 / 10$ & 8.8 & Maule & Ch. 2 & 0.286 & 52.58 & 2.42 & 3.63 \\
\hline 5 & México & $19 / 09 / 85$ & 8.0 & CDAF & N90W & 0.096 & 37.74 & 6.51 & 9.77 \\
\hline 6 & México & $19 / 09 / 85$ & 8.0 & CDAO & N00E & 0.07 & 35.98 & 6.97 & 10.46 \\
\hline 7 & México & $19 / 09 / 85$ & 8.0 & CU01 & S00E & 0.029 & 10.16 & 13.89 & 20.83 \\
\hline 8 & México & $19 / 09 / 85$ & 8.0 & CU01 & N90W & 0.034 & 9.27 & 10.08 & 15.12 \\
\hline 9 & Tohoku (Japan) & $11 / 03 / 11$ & 9.0 & MYG004 & E-W & 1.17 & 58 & 1.77 & 2.65 \\
\hline 10 & Tohoku (Japan) & $11 / 03 / 11$ & 9.0 & MYG004 & N-S & 2.47 & 94 & 1.97 & 2.95 \\
\hline
\end{tabular}

Table 5. Cortical zone. Near-field records.

\begin{tabular}{|c|c|c|c|c|c|c|c|c|c|}
\hline No. & Earthquake & Date & $\boldsymbol{M}_{\mathbf{w}}$ & Station & Comp. & PGA [g] & PGV [cm/s] & $\begin{array}{c}\text { Scale Factor } \\
\text { (DRS) }\end{array}$ & $\begin{array}{c}\text { Scale Factor } \\
\text { (MCE) }\end{array}$ \\
\hline \hline 1 & Cape Mendocino & $04 / 25 / 92$ & 7.0 & Petrolia & $0^{\circ}$ & 0.590 & 48.14 & 2.11 & 3.16 \\
\hline 2 & Cape Mendocino & $04 / 25 / 92$ & 7.0 & Petrolia & $90^{\circ}$ & 0.662 & 89.68 & 1.12 & 1.68 \\
\hline 3 & Chi Chi & $09 / 20 / 99$ & 7.6 & Chi Chi & N-S & 0.603 & 78.82 & 1.03 & 1.54 \\
\hline 4 & Chi Chi & $09 / 20 / 99$ & 7.6 & Chi Chi & E-W & 0.814 & 126.22 & 1.23 & 1.84 \\
\hline 5 & Imperial Valley & $10 / 15 / 79$ & 6.5 & El Centro & $140^{\circ}$ & 0.410 & 64.86 & 1.90 & 2.85 \\
\hline 6 & Imperial Valley & $10 / 15 / 79$ & 6.5 & El Centro & $230^{\circ}$ & 0.439 & 109.82 & 1.98 & 2.97 \\
\hline 7 & Northridge & $01 / 17 / 94$ & 6.7 & Sylmar-Hospital & $90^{\circ}$ & 0.604 & 78.10 & 1.55 & 2.32 \\
\hline 8 & Northridge & $17 / 01 / 94$ & 6.7 & Sylmar-Hospital & $360^{\circ}$ & 0.843 & 129.37 & 1.03 & 1.55 \\
\hline 9 & Erzikan & $03 / 13 / 92$ & 6.7 & Erzikan & N-S & 0.515 & 83.96 & 1.53 & 2.29 \\
\hline 10 & Erzikan & $03 / 13 / 92$ & 6.7 & Erzikan & E-W & 0.496 & 64.28 & 1.50 & 2.25 \\
\hline
\end{tabular}

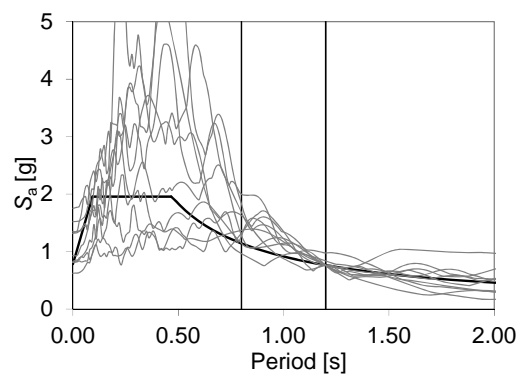

(a) DRS. Cortical records

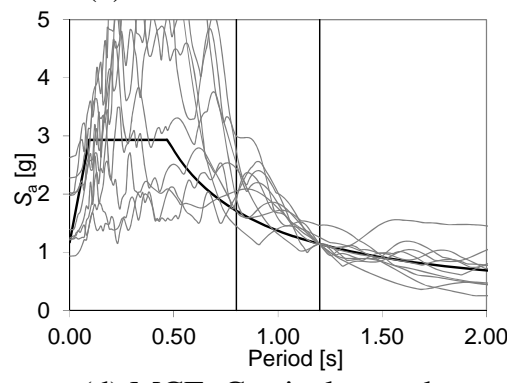

(d) MCE. Cortical records

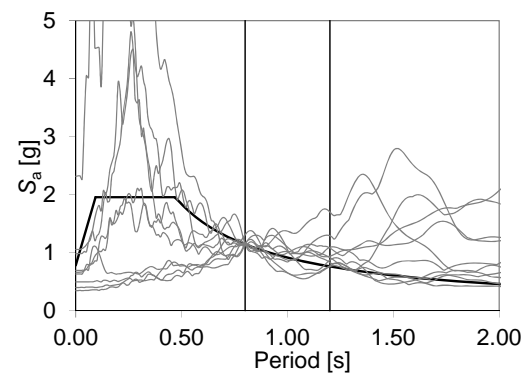

(b) DRS. Subductive records

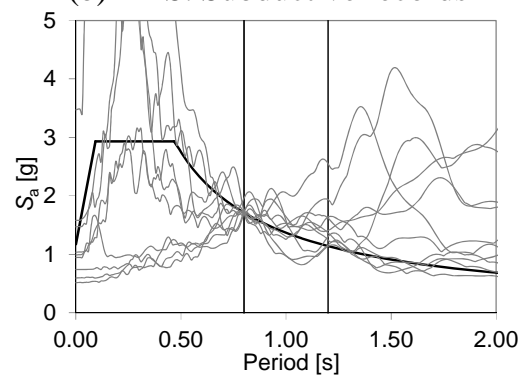

(e) MCE. Subductive records

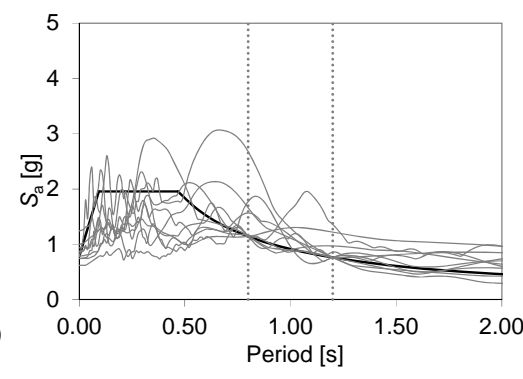

(c) DRS. Near-field records

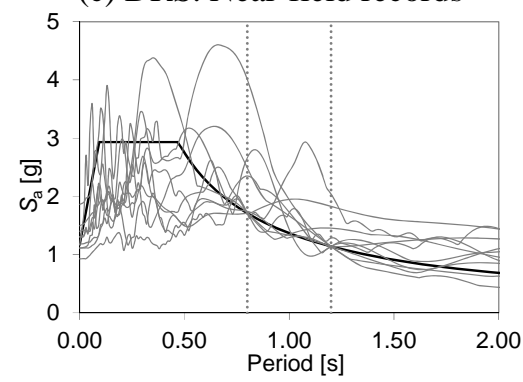

(f) MCE. Near-field records

Fig. (5). Absolute pseudo-acceleration response spectra of the scaled records. 


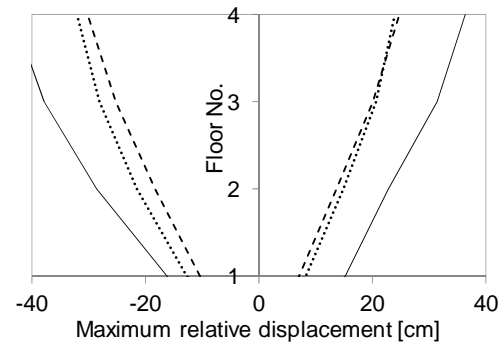

(a) DRS. Cortical records

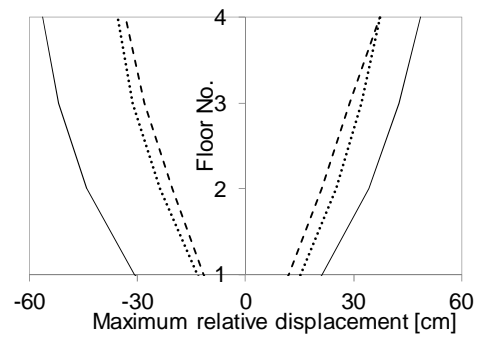

(d) MCE. Cortical records

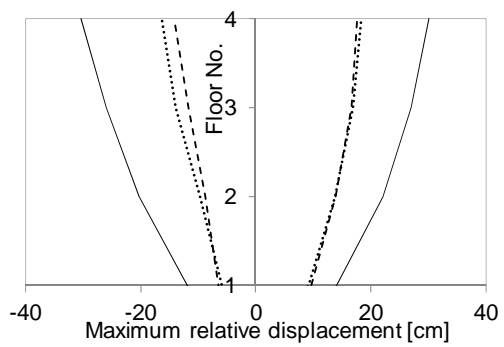

(b) DRS. Subductive records

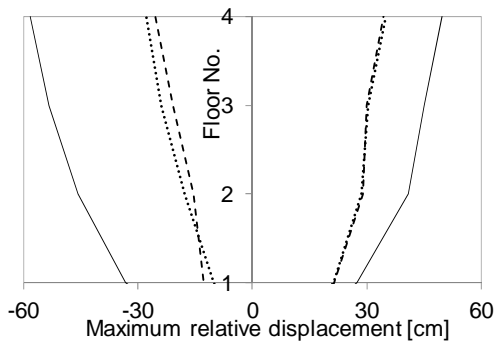

(e) MCE. Subductive records

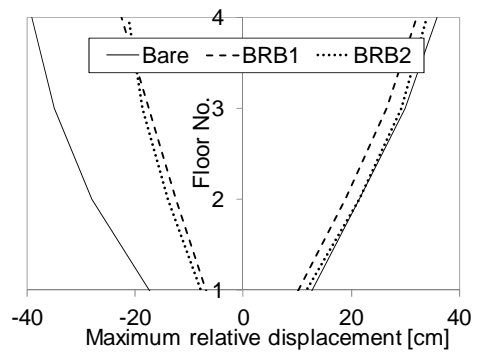

(c) DRS. Near-field records

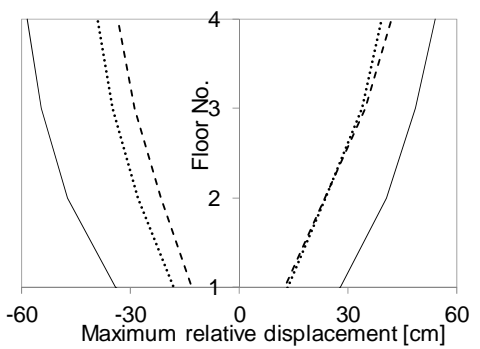

(f) MCE. Near-field records

Fig. (6). Mean values of the maximum relative displacement of each floor with respect to the base.

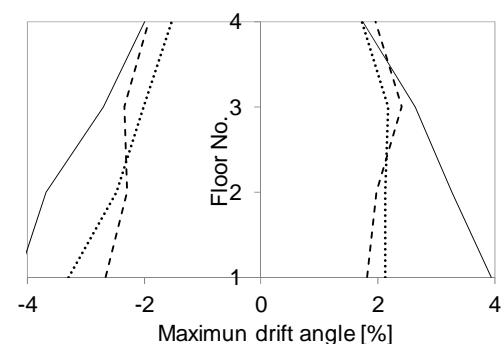

(a) DRS. Cortical records

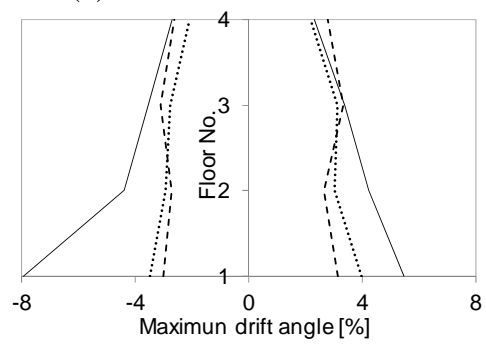

(d) MCE. Cortical records

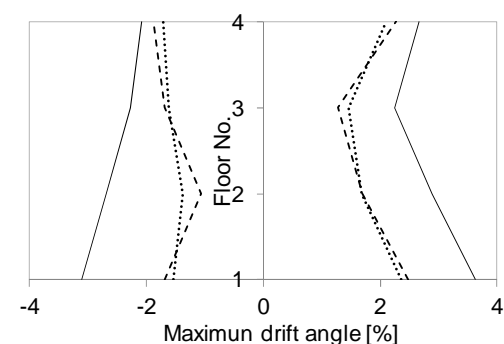

(b) DRS. Subductive records

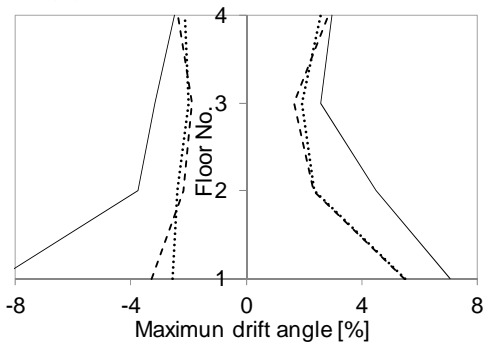

(e) MCE. Subductive records

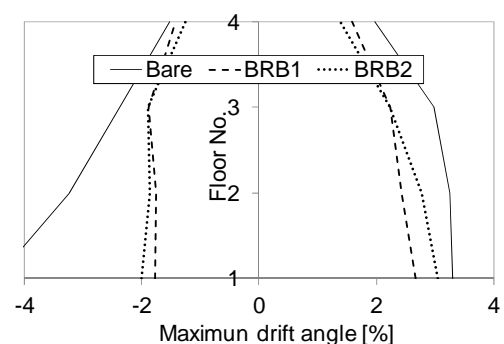

(c) DRS. Near-field records

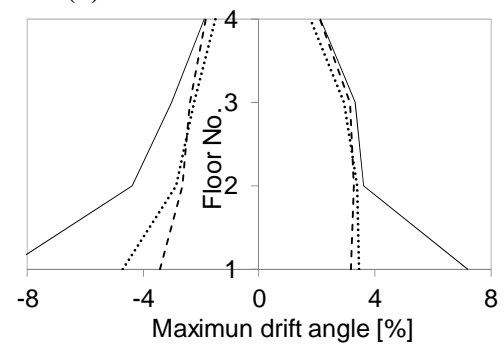

(f) MCE. Near-field records

Fig. (7). Mean values of the maximum interstory drift of each floor.

relative (positive) displacement of the top floor for each record. The results for the record Northridge component $0^{\circ}$ (record No. 7 in Table 3) are omitted in Fig. (6d), Fig. (7d) and Fig. (8d) since, for the MCE level, such record provided extremely high displacements; a careful analysis showed that this fact was due to large structural degradation because of the important severity of the record. Results from Figs. (6 and 7) show that, for all the considered types of records, the buckling-restrained braces are able to reduce the dynamic response in terms of relative displacement and interstory drift; no relevant differences can be observed, neither among cortical, subductive and near-fault records, nor between BRB1 and BRB2, nor between DRS and MCE levels. Fig. (8) shows that the dispersion among the records inside each group is basically equivalent. However, Figs. (8a, $\mathbf{c}, \mathbf{d}$ and $\mathbf{f}$ ) point out that for some cortical and near-fault records the buckling-restrained braces can be either useless or even prejudicial since the corresponding maximum bare frame responses are either not reduced or even amplified.

Similarly to Figs. (6, 7 and 9) displays the average values (for each of the groups of records in Tables 3-5) of the maximum absolute acceleration of each floor. Results from Fig. (9) show that, globally speaking, the buckling-restrained braces are not able to reduce the absolute accelerations.

Fig. (10) displays the maximum values (for each of the groups of records in Tables 3-5) of the permanent relative displacement of each floor with respect to the base. Results from Fig. (10) show that in virtually all the analyzed cases, the buckling-restrained braces are highly efficient to reduce the permanent displacements. 


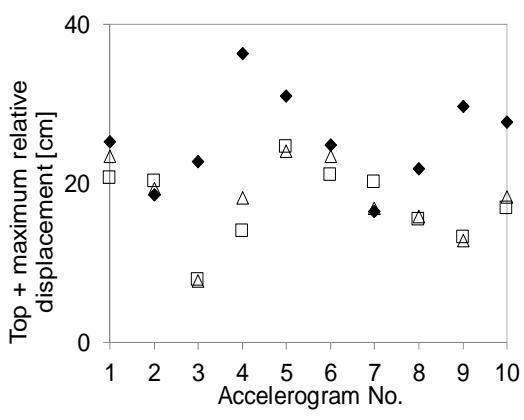

(a) DRS. Cortical records

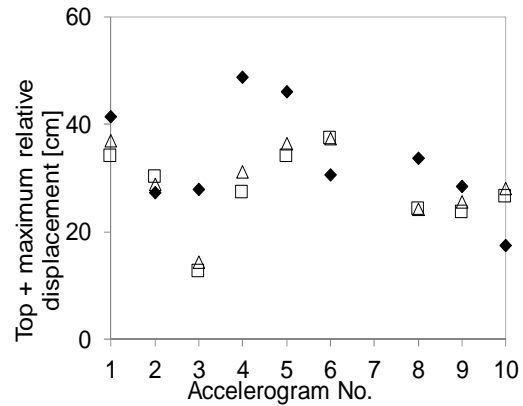

(d) MCE. Cortical records

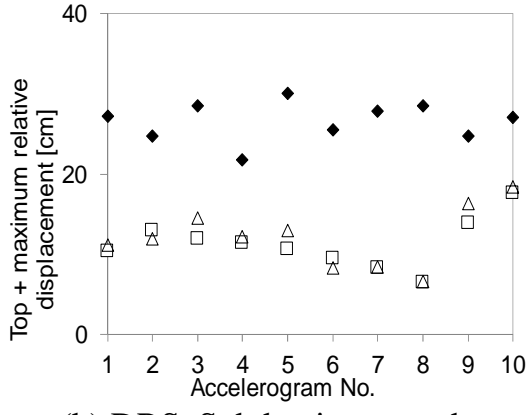

(b) DRS. Subductive records

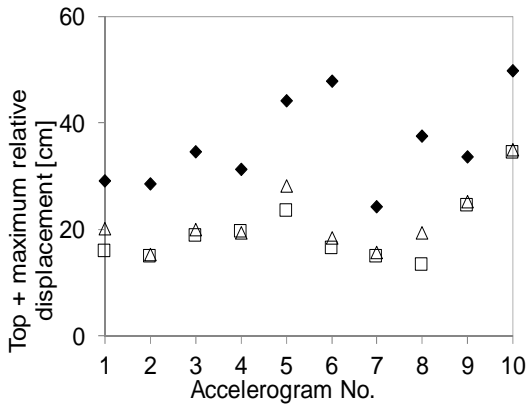

(e) MCE. Subductive records

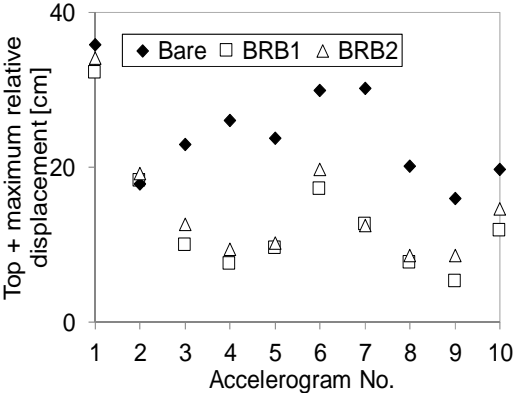

(c) DRS. Near-field records

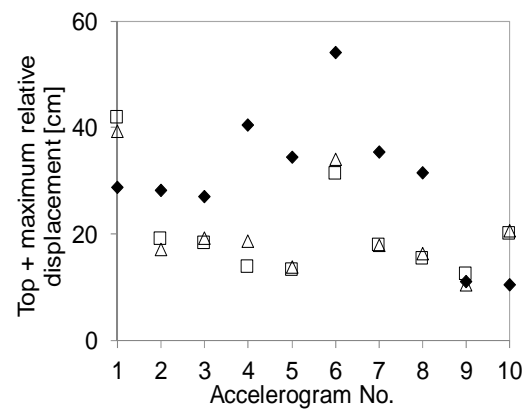

(f) MCE. Near-field records

Fig. (8). Maximum relative displacement of the top floor with respect to the base.

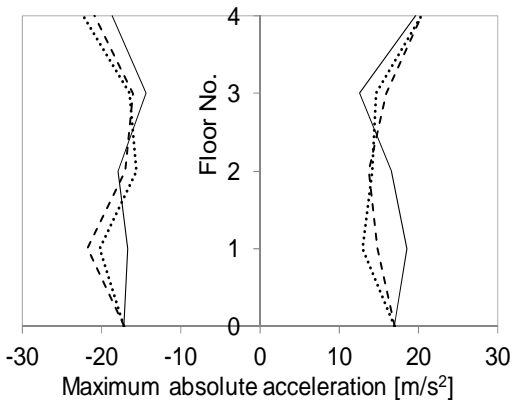

(a) DRS. Cortical records

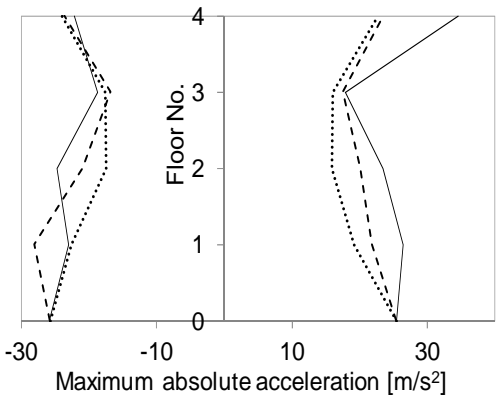

(d) MCE. Cortical records

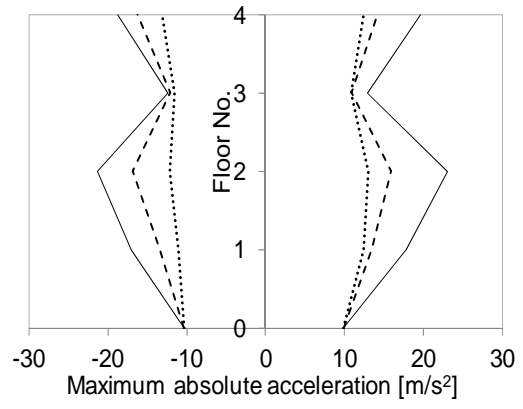

(b) DRS. Subductive records

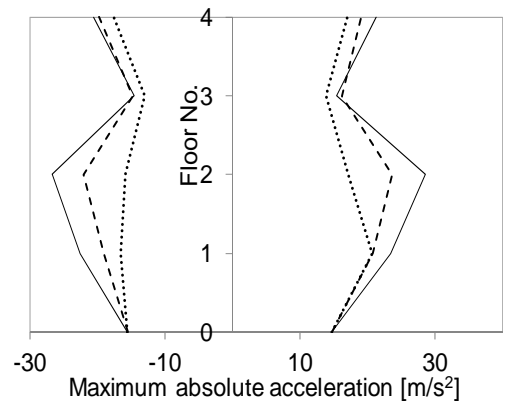

(e) MCE. Subductive records

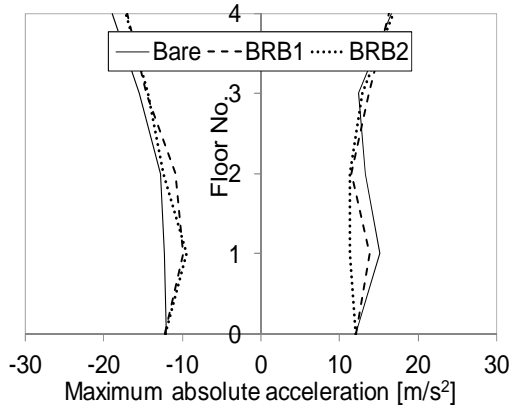

(c) DRS. Near-field records

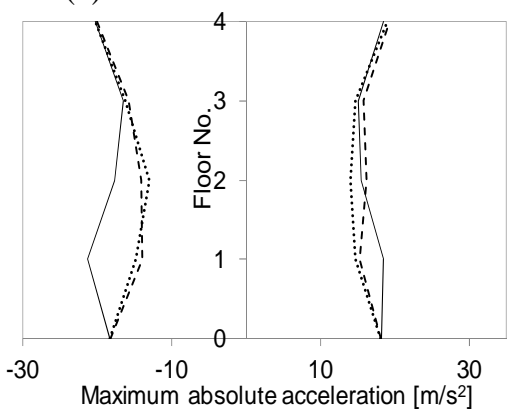

(f) MCE. Near-field records

Fig. (9). Mean values of the maximum absolute acceleration of each floor.

To emphasize the conclusions arising from Figs. (9-12) display a number of time history responses in terms of top floor absolute accelerations and relative displacements (with respect to the base), respectively. To show representative results, a record per type (cortical, subductive and near-fault) and per level (DRS and MCE) is selected. Fig. (11) points out that the buckling-restrained braces are not very efficient in reducing the absolute accelerations and Fig. (12) highlights the aforementioned permanent displacements.
The Housner-Akiyama energy formulation $[51,52]$ is one of the most powerful theoretical tools to analyze the seismic performance of any construction, being particularly well suited for buildings protected with energy dissipators. The work [53] proposes, for high seismicity regions, design energy spectra of relative input energy $E_{\mathrm{I}}$ and of hysteretic energy $E_{\mathrm{H}} ; E_{\mathrm{H}}$ represents the actual potentially damaging energy. By neglecting the residual strain energy, the final 


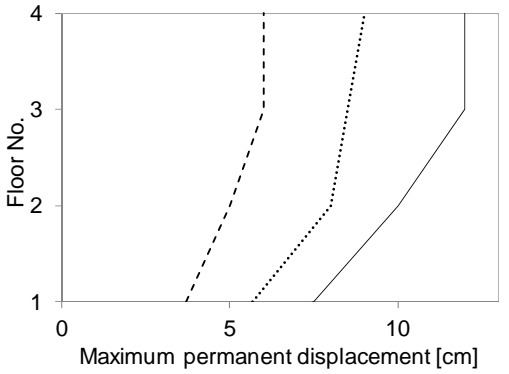

(a) DRS. Cortical records

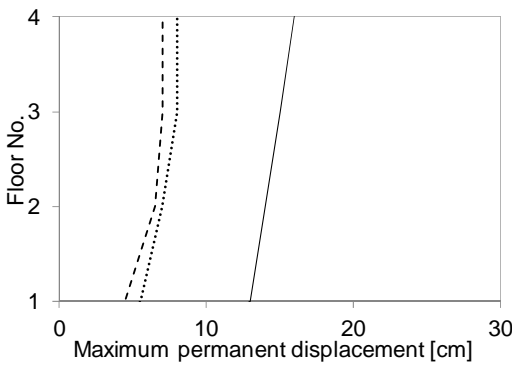

(d) MCE. Cortical records

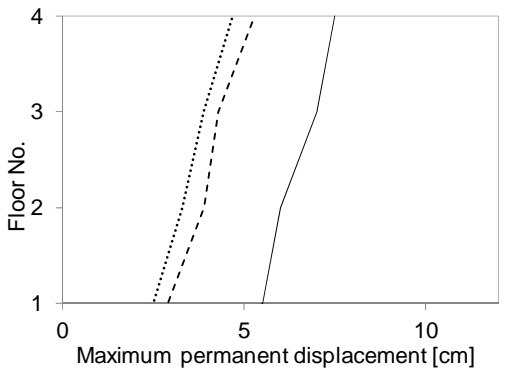

(b) DRS. Subductive records

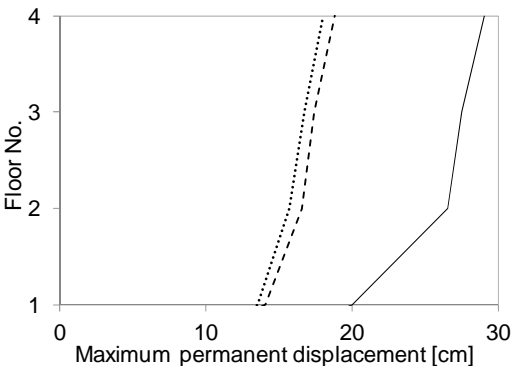

(e) MCE. Subductive records

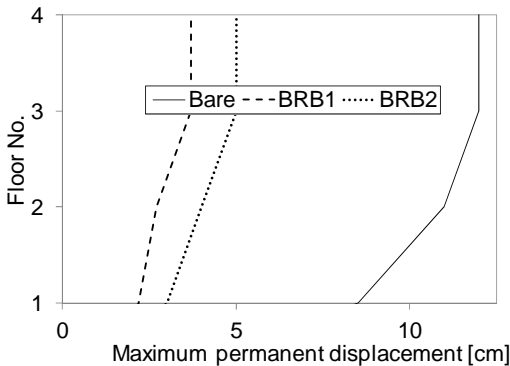

(c) DRS. Near-field records

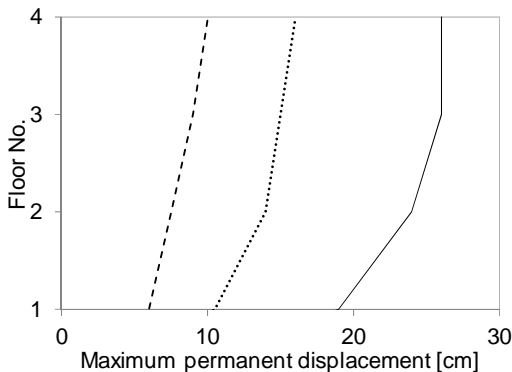

(f) MCE. Near-field records

Fig. (10). Mean values of the maximum permanent relative displacement of each floor with respect to the base.

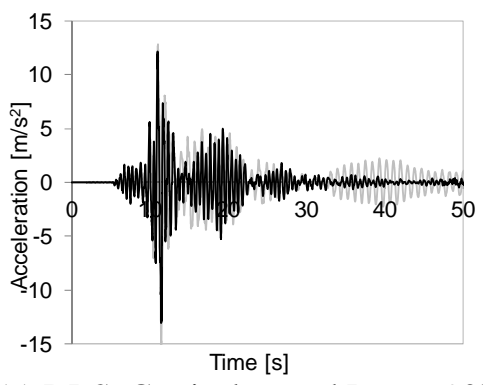

(a) DRS. Cortical record Duzce $90^{\circ}$

(No. 10, Error! Reference source not found.)

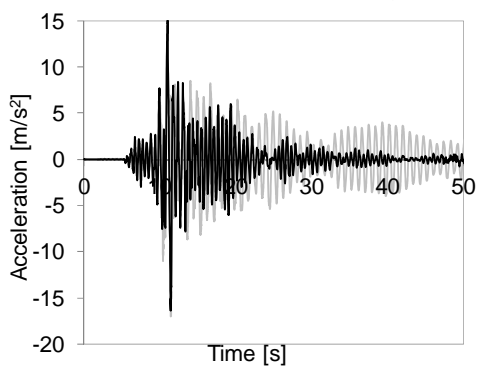

(d) MCE. Cortical record Duzce $90^{\circ}$

(No. 10, Error! Reference source not found.)

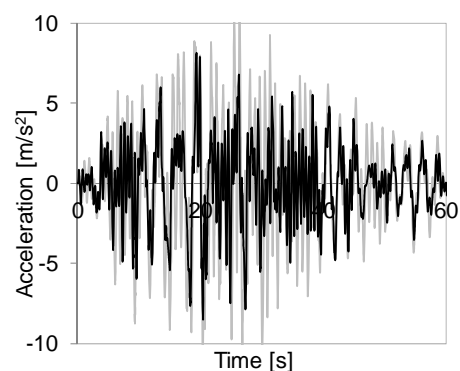

(b) DRS. Subductive record Mexico CDAF (No. 5, Error! Reference source not found.)

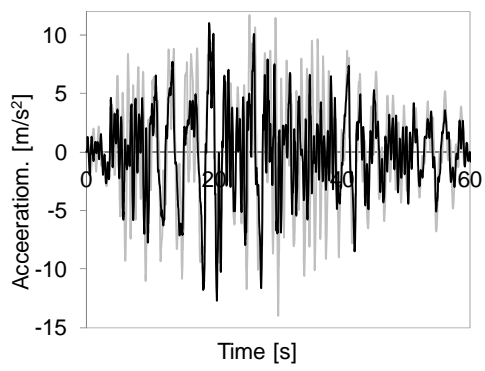

(e) MCE. Subductive record Mexico CDAF (No. 5, Error! Reference source not found.)

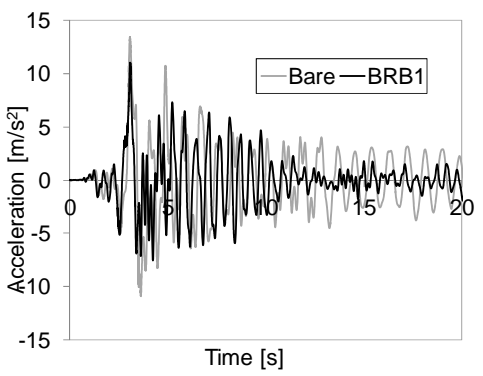

(c) DRS. Near-field record Erzikan NS (No. 9, Error! Reference source not found.)

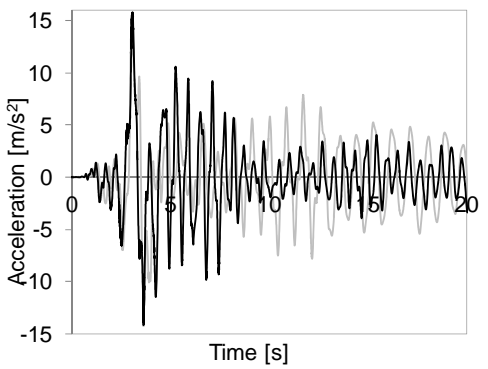

(f) MCE. Near-field record Erzikan NS (No. 9, Error! Reference source not found.)

Fig. (11). Time histories of the top floor absolute acceleration.

energy balance equation is written as $E_{\mathfrak{x}}+E_{\mathrm{H}}=E_{\mathrm{I}}$ where $E_{\zeta}$ is the energy dissipated by damping, given by $E_{æ}=\int \dot{\mathbf{x}}^{\mathrm{T}} \mathbf{C} \dot{\mathbf{x}} d t ; \mathbf{C}$ is the viscous damping matrix and $\dot{\mathbf{x}}$ is the relative velocity vector. The input energy is
$E_{\mathrm{I}}=-\int \dot{\mathbf{x}}^{\mathrm{T}} \mathbf{M r} \ddot{z}_{\mathrm{g}} d t$ where $\mathbf{M}$ is the mass matrix, $\mathbf{r}$ is the collocation vector $\left(\mathbf{r}=(1, \ldots, 1)^{\mathrm{T}}\right)$ and $\ddot{z}_{\mathrm{g}}$ is the input ground acceleration. Both the input and the hysteretic energy spectra are formulated in terms of equivalent velocity through $V_{\mathrm{E}}$ 


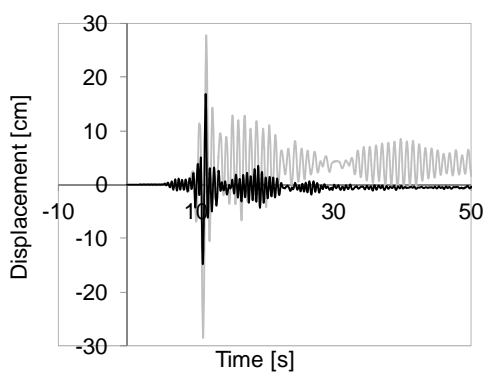

(a) DRS. Cortical record Duzce $90^{\circ}$

(No. 10, Error! Reference source not found.)

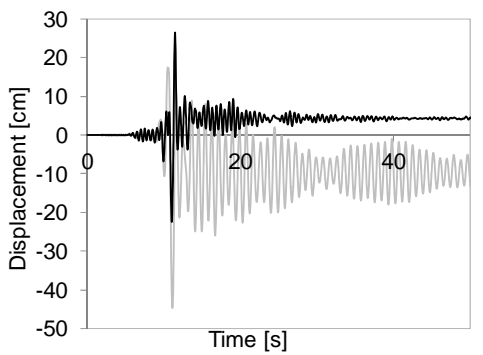

(d) MCE. Cortical record Duzce $90^{\circ}$

(No. 10, Error! Reference source not found.)

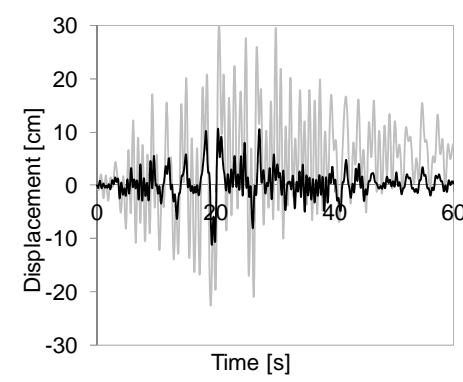

(b) DRS. Subductive record México

CDAF (No. 5, Error! Reference source not found.)

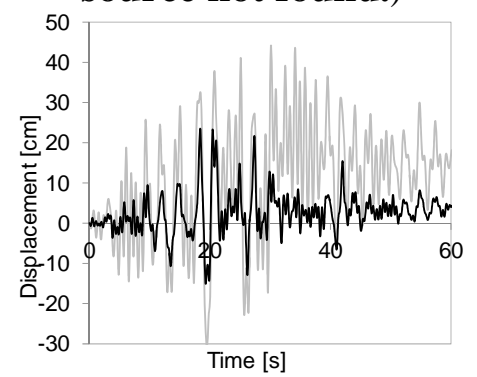

(e) MCE. Subductive record México CDAF (No. 5, Error! Reference source not found.)

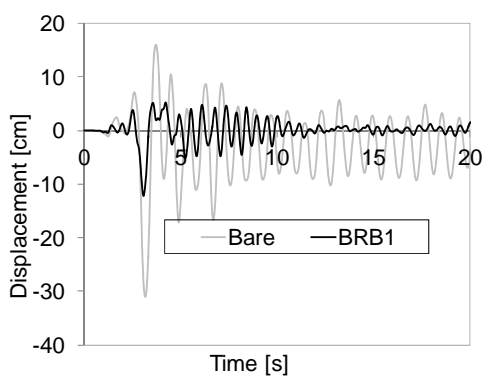

(c) DRS. Near-field record Erzikan NS (No. 9, Error! Reference source not found.)

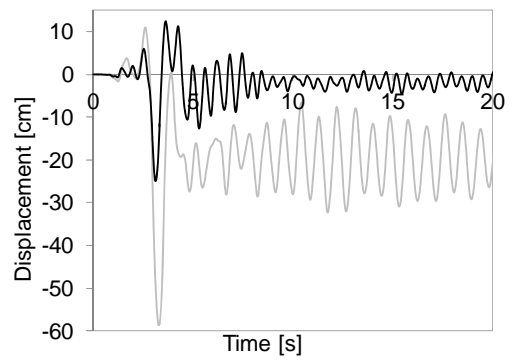

(f) MCE. Near-field record Erzikan NS (No. 9, Error! Reference source not found.)

Fig. (12). Time histories of the relative displacement of the top floor with respect to the base.

and $V_{\mathrm{D}}$, respectively. $V_{\mathrm{E}}$ and $V_{\mathrm{D}}$ are given by $V_{E}=\sqrt{2 E_{1} / m}$ and $V_{D}=\sqrt{2 E_{H} / m}$ where $m$ is the mass of the building. Input energy spectra $\left(V_{\mathrm{E}}\right)$ are dependent on soil type (e.g. stiff / soft), PGA (design peak ground acceleration), magnitude of expected seismic events (e.g. $\left.M_{\mathrm{s}} \leq 5.5 / M_{\mathrm{s}}>5.5\right)$ and input type (near-fault / far-fault records); conversely, are independent on mass and damping. Furthermore, except for short periods, $V_{\mathrm{E}}$ spectra are also independent on hysteretic structural behavior. The hysteretic energy spectra $\left(V_{\mathrm{D}}\right)$ are obtained from the $V_{\mathrm{E}}$ spectra as $V_{\mathrm{D}}=V_{\mathrm{E}}\left(V_{\mathrm{D}} / V_{\mathrm{E}}\right)$; criteria for obtaining the ratio $V_{\mathrm{D}} / V_{\mathrm{E}}$ in terms of period $(T)$, damping $(\zeta)$ and displacement ductility $(\mu)$ are given.

In the considered building the weight is $W=2.113 \mathrm{MN}$ [38]; the fundamental periods are not relevant since lie in the plateau of the design spectra. Given that the considered inputs are severe (Tables 3-5) it is assumed that $M_{\mathrm{s}}>5.5$. Four values of $V_{\mathrm{E}}$ are obtained: $V_{\mathrm{E}}=395 \mathrm{~cm} / \mathrm{s}$ (soft soil $/$ nearfault records), $V_{\mathrm{E}}=266 \mathrm{~cm} / \mathrm{s}$ (soft soil $/$ far-fault records), $V_{\mathrm{E}}$ $=364 \mathrm{~cm} / \mathrm{s}$ (stiff soil $/$ near-fault records) and $V_{\mathrm{E}}=181 \mathrm{~cm} / \mathrm{s}$ (stiff soil/far-fault records). Such values correspond to characteristic spectra, i.e. $95 \%$ percentile. For a damping factor $\zeta=0.05$ and for a displacement ductility $\mu=5$ the ratio $V_{\mathrm{D}} / V_{\mathrm{E}}$ is approximately equal to 0.801 for the unbraced building $\left(T_{\mathrm{F}}=0.8 \mathrm{~s}\right.$, Table 2$)$ and to 0.814 for the braced building $\left(T_{\mathrm{F}}=0.53 \mathrm{~s}\right.$, this section). For the most demanding case (soft soil/near-fault records) the input and hysteretic energies are respectively given by

$$
\begin{aligned}
& E_{1}=\frac{1}{2} m V_{E}^{2}=\frac{1}{2} \times 2.113 \times 10^{5} \times 3.95^{2}=1.65 \mathrm{MJ}=1648 \mathrm{kNm} \\
& E_{H}=\frac{1}{2} m V_{D}^{2}=\frac{1}{2} \times 2.113 \times 10^{5} \times(3.95 \times 0.814)^{2}=1.09 \mathrm{MJ}=1092 \mathrm{kNm}
\end{aligned}
$$

For the soft soil / far-fault records case the input and hysteretic energies are

$$
\begin{aligned}
& E_{1}=\frac{1}{2} m V_{E}^{2}=\frac{1}{2} \times 2.113 \times 10^{5} \times 2.66^{2}=0.75 \mathrm{MJ}=748 \mathrm{kNm} \\
& E_{H}=\frac{1}{2} m V_{D}^{2}=\frac{1}{2} \times 2.113 \times 10^{5} \times(2.66 \times 0.814)^{2}=0.49 \mathrm{MJ}=495 \mathrm{kNm}
\end{aligned}
$$

To compare with the obtained results, Tables 6-8 display the input energy and the energy dissipated by the bucklingrestrained braces for the inputs listed in Tables 3-5, respectively. Only the accelerograms scaled for MCE are considered.

\section{Results from Tables 6-8 show that:}

- The input energy exhibits a high dispersion among the considered inputs, both for the bare and protected frames. For the bare frame, it ranges between $265 \mathrm{kNm}$ (Northridge earthquake, Sylmar-Hospital $360^{\circ}$ record; Table 8) and $5040 \mathrm{kNm}$ (México earthquake, CDAO N00E record; Table 7); for the frame protected with buckling-restrained braces the minimum value is 663 $\mathrm{kNm}$ (Northridge earthquake, Sylmar-Hospital $360^{\circ}$ record, BRB1; Table 8) and the maximum value is 10862 kNm (México earthquake, CDAO N00E record, BRB1; Table 7). Comparison with the values provided by the energy spectra show that for near-fault records they are similar to the average value but for far-fault records they are highly unconservative. 
Table 6. Energy balance for the MCE level. Cortical zone. Far -field records.

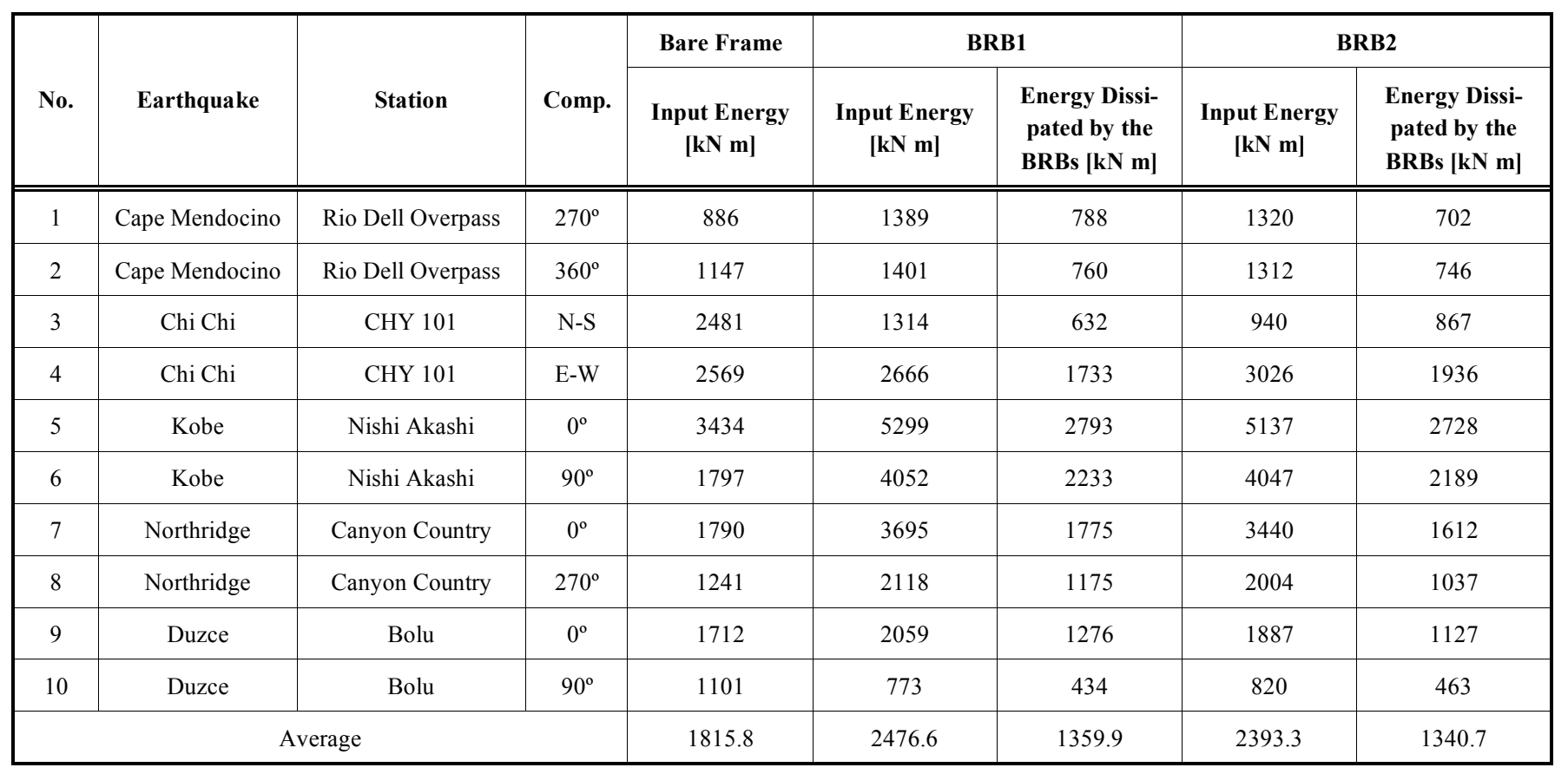

Table 7. Energy balance for the MCE level. Subductive zone. Far-field records.

\begin{tabular}{|c|c|c|c|c|c|c|c|c|}
\hline No. & Earthquake & Station & Comp. & $\begin{array}{c}\text { Bare Frame } \\
\text { Input Energy } \\
{[\mathrm{kN} \mathrm{m]}}\end{array}$ & \multicolumn{2}{|c|}{ BRB1 } & \multicolumn{2}{|c|}{ BRB2 } \\
\hline 1 & Pisco (Perú) & La Molina & E-W & 5057 & 6179 & 5157 & 5787 & 4690 \\
\hline 2 & Pisco (Perú) & La Molina & N-S & 3345 & 10862 & 8160 & 10115 & 7794 \\
\hline 4 & Maule (Chile) & Maule & Ch. 2 & 3956 & 4164 & 2939 & 4287 & 3065 \\
\hline 5 & México & CDAF & N90W & 3190 & 1676 & 1181 & 1992 & 1282 \\
\hline 6 & México & CDAO & NO0E & 5040 & 2065 & 1567 & 2539 & 1883 \\
\hline 10 & Tohoku (Japan) & MYG004 & N-S & - & - & - & - & - \\
\hline \multicolumn{4}{|c|}{ Average } & 3722.7 & 3994.2 & 3008.2 & 4061.4 & 3076.2 \\
\hline
\end{tabular}

- The input energies for bare and protected frames are highly dissimilar. The ratio between the values for bare and BRB1 ranges between 0.291 (Maule earthquake, Ch. 1 record; Table 8) and 4.572 (México earthquake, CU01 N90W record; Table 7). For the average BRB1 values, the ratios are 0.733 (Table 6), 0.933 (Table 7) and 1.058 (Table 8).

- The input energies for BRB1 and BRB2 are rather similar. The ratio between the values for $\mathrm{BRB} 1$ and $\mathrm{BRB} 2$ ranges between 0.728 (México earthquake, CU01 N90W record; Table 7) and 1.398 (Chi Chi earthquake, CHY $101 \mathrm{~N}-\mathrm{S}$ record; Table 6). For the average values, the ratios are 1.035 (Table 6), 0.983 (Table 7) and 0.966 (Table 8).

- The percentage of input energy that is absorbed by buckling-restrained braces is reasonably stable. That percentage ranges between 47\% (Northridge earthquake, Canyon Country $0^{\circ}$ record, BRB2; Table 6) and $92 \%$ 
Table 8. Energy balance for the MCE level. Cortical zone. Near-field records.

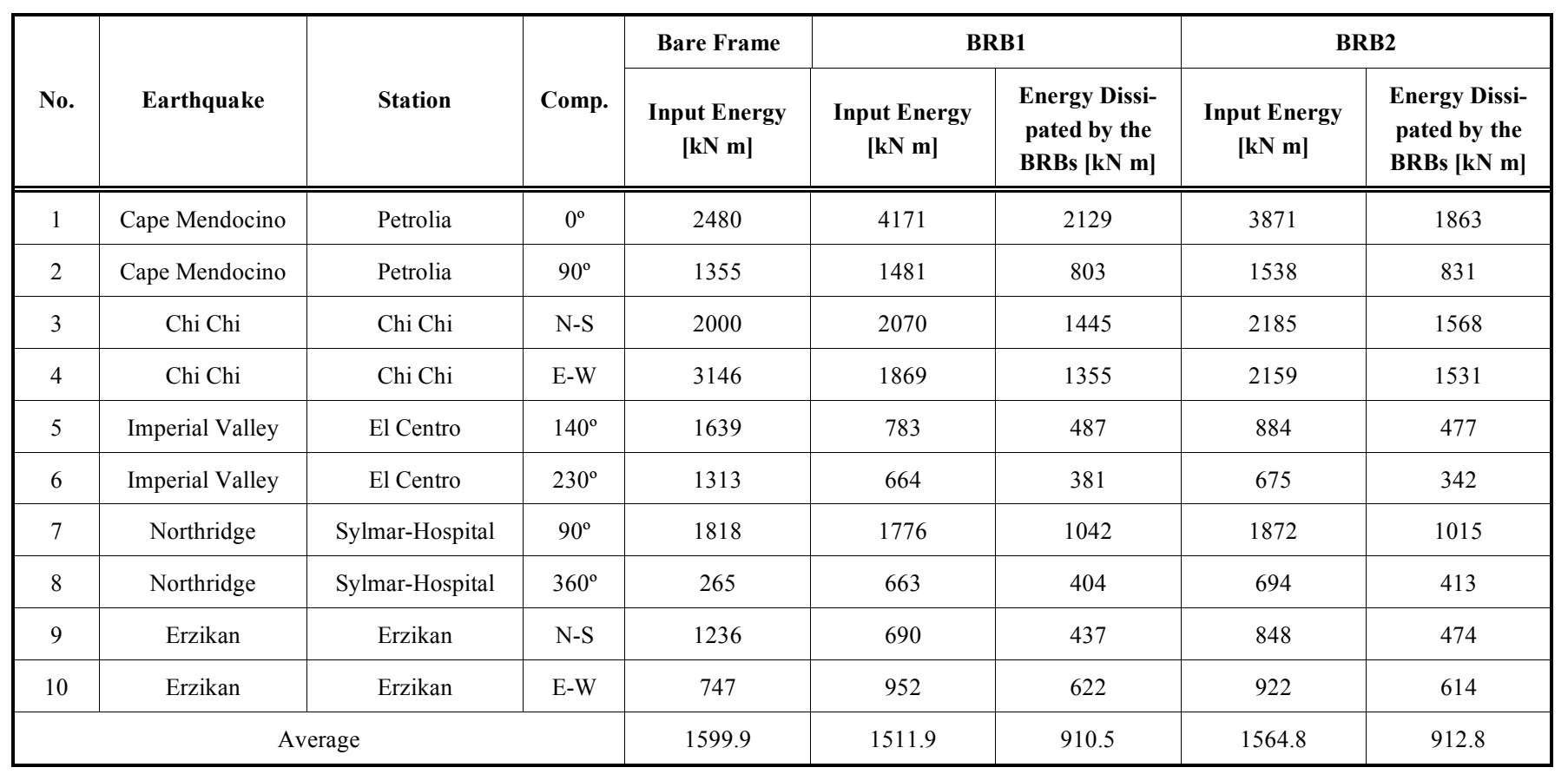

(Chi Chi earthquake, CHY $101 \mathrm{E}-\mathrm{W}$ record, BRB2; Table 6). For the average BRB1 values, ratios are $55 \%$ (Table 6), 75\% (Table 7) and 60\% (Table 8). Comparison with the aforementioned $V_{\mathrm{D}} / V_{\mathrm{E}}$ ratio (equal to 0.814 for the braced frame) shows that most of the damaging part of the energy is absorbed by bucklingrestrained braces.

These conclusions (mainly the strong dissimilarity between the input energies for bare and protected frames) point out the difficulty of estimating the efficiency of the buckling-restrained braces in terms of energy balance. Noticeably, for many inputs, the allegedly protecting devices increase significantly the input energy.

\section{CONCLUSION}

This paper presents a numerical study on the seismic efficiency of buckling-restrained braces for reducing the seismic response of short-height frame buildings under several types of inputs. The inputs consists of three groups of ten records each; the first group includes cortical far-fault records, the second group contains subductive far-fault records and the third group holds near-fault records. All the accelerograms are scaled to uniform their spectral ordinates in the relevant range of periods; each record is scaled with two factors corresponding to the "Design Response Spectrum" (DRS) and to the "Maximum Considered Earthquake" (MCE). The considered building is a symmetric four-story steel frame that was tested at the E-defense laboratory; the availability of such experimental information allows calibrating the numerical modelling of the building. The building is equipped with buckling-restrained braces at each floor; the devices are designed by two different approaches proposed by the authors. The overall conclusion of this paper is that the buckling-restrained braces are able to reduce the dynamic displacement response of the frame and that no significant differences can be observed among the efficiency for farfault and near- fault records and for DRS and MCE levels. Particular conclusions are summarized below:

- For all the considered types of records, the bucklingrestrained braces are able to reduce the dynamic response in terms of relative displacement and interstory drift; no relevant differences can be observed, neither among cortical, subductive and near-fault records, nor between DRS and MCE levels. The dispersion among the records inside each group is basically equivalent.

- Globally speaking, the buckling-restrained braces are not able to reduce the absolute accelerations of the frame.

- The buckling-restrained braces are highly efficient to reduce the permanent displacements.

- The input energy exhibits a high dispersion among the considered inputs, both for the bare and protected frames; as well, the input energies for bare and protected frames are highly dissimilar. Conversely, the input energies for BRB1 and BRB2 are rather similar and the percentage of the input energy that is dissipated by the buckling-restrained braces is reasonably stable. Most of the damaging energy is dissipated by the bucklingrestrained braces.

\section{CONFLICT OF INTEREST}

The authors confirm that this article content has no conflict of interest.

\section{ACKNOWLEDGEMENTS}

The financial support of the Argentinian Secretariat of University Politics permitted the meetings of the authors in 
Spain and in Argentina; this help is gratefully acknowledged. This paper has been also financed by the Spanish Government under projects CGL2008-00869/BTE and CGL201123621. The useful help of students Ezequiel Toum and Marcelo Carreño in the calculations is highly appreciated.

\section{REFERENCES}

[1] G. W. Housner, L. A. Bergman, T. K. Caughey, A. G. Chassiakos, R. O. Claus, S. F. Masri, R. E. Skelton, T. T. Soong, B. F. Spencer, and J. T. P. Yao, "Structural control: past, present, and future", Journal of Engineering Mechanics ASCE, vol. 123, pp. 897-971, 1997.

[2] T. Soong, and G. Dargush. Passive energy Dissipation Systems in Structural Engineering, John Wiley, 1997.

[3] A. Martelli, "Modern seismic protection systems for civil and industrial structures." In: An Advanced Approach to Earthquake Risk Scenarios, with Applications to Different European Towns, 2006, pp. 1-28, Available: http://www.samco.org/network/download_ area/paper_martelli.pdf [Accessed April 2015].

[4] A. Watanabe, Y. Hitomi, E. Saeki, A. Wada, and M. Fujimoto, "Properties of Brace Encased in Buckling-Restraining Concrete and Steel Tube", In: Proceedings of the Ninth World Conference on Earthquake Engineering, Japan Association for Earthquake Disaster Prevention, Tokyo-Kyoto. Japan, vol. IV, 1988, pp. 719-724.

[5] P. Clark, I. Aiken, K. Kasai, E. Ko, and I. Kimura, "Design Procedures for Buildings Incorporating Hysteretic Damping Devices", In: Proceedings of the $68^{\text {th }}$ Annual Convention. Structural Engineers Association of California, Sacramento, 1999, pp. 355-371.

[6] M. Iwata, "Applications-Design of Buckling-Restrained Braces in Japan", In: $13^{\text {th }}$ World Conference on Earthquake Engineering, Paper no. 3208, Vancouver, Canada, 2004.

[7] K. C. Tsai, J. W. Lai, Y. C. Hwang, S. L. Lin, and C. H. Weng, "Research and application of double-core buckling-restrained braces in Taiwan", In: $13^{\text {th }}$ World Conference on Earthquake Engineering, Paper no. 2179, Vancouver, Canada, 2004.

[8] W. A. López, "On Designing with Buckling-Restrained Braced Frames", Structure Magazine, p. 41, 2008.

[9] A. P. Brown, I. D. Aiken, and F. J. Jafarzadeh, "Buckling Restrained Braces Provide the Key to the Seismic Retrofit of the Wallace F. Bennett Federal Building", Modern Steel Construction, 2001, Available: http://www.reaveley.com/news/publications/overview_ bennettbuilding_parry_brown.pdf

[10] C. Black, N. Makris, and L. Aiken, "Component testing, seismic evaluation and characterization of buckling restrained braces", Journal of Structural Engineering ASCE, vol. 130, pp. 329-337, 2004.

[11] W. A. López, D. S. Gwie, T. W. Lauck, and M. Saunders, "Structural design and experimental verification of a buckling-restrained braced frame system", Engineering Journal, vol. 41, no. 4, pp. 177186, 2004.

[12] R. Tremblay, P. Bolduc, R. Neville, and R. De Vall, "Seismic testing and performance of buckling-restrained bracing systems", $\mathrm{Ca}$ nadian Journal of Civil Engineering, vol. 33, pp. 183-198, 2006.

[13] A. Wada, and M. Nakashima, "From infancy to maturity of buckling-restrained braces research", In: $13^{\text {th }}$ World Conference on Earthquake Engineering, Paper no. 1732, Vancouver, Canada, 2004.

[14] K. Lee, and M Bruneau, "Energy dissipation of compression members in concentrically braced frames: review of experimental data", Journal of Structural Engineering ASCE, vol. 131, pp. 552-559, 2005.

[15] M. D’Aniello, G. Della Corte, F. M. Mazzolani, and R Landolfo, "Steel Buckling-Restrained Braces", In: Seismic upgrading of $R C$ buildings by advanced techniques, The ILVA-IDEM Research Project, Polimetrica Publisher, Italy, 2006, pp. 179-223.

[16] J. Newell, C. M. Uang, and G. Benzoni, "Subassemblage testing of core brace buckling-restrained braces ( $G$ Series)", University of California San Diego, Report No. TR-2006/01, 2006.

[17] R. Tremblay, G. Degrange, and J. Blouin, "Seismic Rehabilitation of a Four-Storey Building with a Stiffened Bracing System", In: $8^{\text {th }}$ Canadian Conference on Earthquake Engineering, Canadian Association for Earthquake Engineering, Vancouver, 1999, pp. 549-554.

[18] K. Kasai, and M. Kibayashi, "JSSI manual for building passive control technology. PART-1 Manual contents and design/analysis methods", In: $13^{\text {th }}$ World Conference on Earthquake Engineering, Paper no. 2989, Vancouver, Canada, 2004.

[19] M. Kibayashi, K. Kasai, Y. Tsuji, M. Kikuchi, Y. Kimura, T. Kobayashi, H. Nakamura, and Y. Matsuba, "JSSI manual for building passive control technology. PART-2 Criteria for implementation of energy dissipation devices", In: $13^{\text {th }}$ World Conference on Earthquake Engineering, Paper no. 2990, Vancouver Canada, 2004.

[20] R. Sabelli, and I. Aiken, "US building-code provisions for buckling-restrained braced frames: basis and development", In: $13^{\text {th }}$ World Conference on Earthquake Engineering, Paper no. 1828, Vancouver, Canada, 2004.

[21] L. A. Fahnestock, R. Sause, and J. M. Ricles, "Seismic analysis and design of buckling-restrained braced frames", In: $5^{\text {th }}$ International PhD Symposium in Civil Engineering, Walraven, Blaauwendraad, Scarpas and Snijder, Eds. Taylor \& Francis, 2004.

[22] M. Astrella, and A. Whittaker, "The Performance-Based Design Paradigm", MCERR Report MCEER-05-0011 2005, 2005.

[23] R. Sabelli, W. Pottebaum, J.C. Brazier, and W.A. López, "Design of a Buckling-Restrained Braced Frame Utilizing 2005 Seismic Standards. Metropolis \& Beyond 2005", In: Proceedings of the 2005 Structures Congress and the Forensic Engineering Symposium, New York, 2005.

[24] H. Choi, and J. Kim, "Energy-based seismic design of bucklingrestrained braced frames using hysteretic energy spectrum", Engineering Structures, vol. 28, pp. 304-311, 2006.

[25] AISC 341,"Seismic Provisions for Structural Steel Building", American Institute of Steel Construction, 2005.

[26] G. Palazzo, F. Crisafulli, "Estudio Comparativo de Distintos Disipadores por Fluencia en Base a los Requerimientos Establecidos en Distintas Normas", XXXI Jornadas Sud-Americanas de Ingeniería Estructural, Mendoza. Argentina, 2004.

[27] D. Foti, L. M. Bozzo, and F. L. Almansa, "Numerical Efficiency Assessment of Energy Dissipators for Seismic Protection of Buildings", Earthquake Engineering \& Structural Dynamics, vol. 27, pp. 543-556, 1998.

[28] S. Kiggins, C. M. Uang, "Reducing residual drift of bucklingrestrained braced frames as a dual system", Engineering Structures, vol. 28, pp. 1525-1532, 2006.

[29] Z. Baghbanijavid, A. Jalali, and Y. Yasrebinia, "Seismic Response of Buckling-Restrained Braces under Near-Fault Ground Motions", Journal of Applied Sciences, vol. 10, no. 23, pp. 2967-2977, 2010.

[30] M. Tada, M. Ohsaki, S. Yamada, S. Motoyui, and K. Kasai, " $E-$ Defense Test on Full-Scale Steel Buildings: Part 3- Analytical Simulation of Collapse", NEES/E-Defense collaborative research program on steel structures, 2007.

[31] S. Yamada, K. Suita, K. Tada, K. Kasai, Y. Matsuoka, Y. Shimada, "Collapse experiment on 4-story steel moment frame: Part 1 outline of test results", In: $14^{\text {th }}$ World Conference on Earthquake Engineering, Beijing, China, 2008.

[32] M. Ohsaki, K. Kasai, G. Thiagarajan, Y. Yang, and Y. Komiya, "3$\mathrm{D}$ analysis methods for 2007 blind analysis contest", In: $14^{\text {th }}$ World Conference on Earthquake Engineering, Beijing, China, 2008.

[33] G. Palazzo, F. Crisafulli, F. L. Almansa, and X. Cahís, "Análisis numérico experimental de barras de pandeo restringido", XIX Jornadas Argentinas de Ingeniería Estructural, Mar del Plata Argentina, 2006.

[34] G. Palazzo, F. López-Almansa, X. Cahís, and F Crisafulli, “Theoretical and Experimental Analysis of Dissipative Buckling Restrained Braces", CIMNE Monograph Report IS-64, 2011.

[35] G. Palazzo, F. López-Almansa, X. Cahís, and F Crisafulli, "A lowtech dissipative buckling-restrained brace. Design, analysis, production and testing", Engineering Structures, vol. 31, pp. 2152-2161, $2009 \mathrm{~b}$.

[36] J. C. Castro-Medina, "Numerical modelling of the structural behavior of buckling-restrained braces (in Spanish)", Doctoral Dissertation, Technical University of Catalonia, Barcelona, Spain, 2011.

[37] F. López Almansa, J. C. Castro, and S. Oller, "A numerical model of the structural behavior of buckling-restrained braces", Engineering Structures, vol. 41, no. 1, pp. 108-117, 2012.

[38] A. Pavan, "Blind prediction of a full-scale $3 d$ steel frame tested under dynamic conditions", MSc Dissertation, Centre for PostGraduate Training and Research in Earthquake Engineering and Engineering Seismology (ROSE School), Pavia, Italy, 2008.

[39] B. F. Maison, K. Kasai, and G. Deirlein, "ASCE-41 and FEMA-351 evaluation of E-defense collapse test", Earthquake Spectra, vol. 25, no. 4, pp. 927-953, 2009. 
[40] D. Lignos, T. Hikino, Y. Matsuoka, and M. Nakashima, "Collapse Assessment of Steel Moment Frames Based on E-Defense FullScale Shake Table Collapse Tests", Journal of Structural Engineering ASCE, vol. 139, no. 1, pp. 120-132, 2013.

[41] G. Palazzo, "Rehabilitation of seismic RC frames thru buckling restrained braces", PhD Dissertation, National Technological University, Mendoza, Argentina, 2009a.

[42] INPRES-CIRSOC 103. "Normas Argentinas Para Construcciones Sismorresistentes", Instituto nacional de prevención sísmica, 1991.

[43] SeismoSoft, "SeismoStruct - A Computer Program for Static and Dynamic Nonlinear Analysis of Framed Structures", V. 5.2.2, 2011, Available: www.seismosoft.com.

[44] J. B. Mander, M. J. N. Priestley, and R. Park, "Theoretical stressstrain model for confined concrete", Journal of Structural Engineering, vol. 114, no. 8, pp. 1804-1826, 1988.

[45] J. E. Martínez-Rueda, and A. S. Elnashai, "Confined concrete model under cyclic load", Materials and Structures, vol. 30, no. 197, pp. 139-147, 1997.

[46] P. Madas, "Advanced Modelling of Composite Frames Subjected to Earthquake Loading", $\mathrm{PhD}$ Thesis, Imperial College, University of London, London, UK, 1993.
[47] F. A. Charney, "Unintended consequences of modeling damping in structures", Journal of Structural Engineering, vol. 134, no. 4, pp. 581-592, 2008. doi: 10.1061/(ASCE)0733-9445(2008)134:4(581).

[48] H. M. Hilber, T. J. R. Hughes, and R. L. Taylor, "Improved numerical dissipation for time integration algorithms in structural dynamics", Earthquake Engineering and Structural Dynamics, vol. 5, pp. 283-292, 1977.

[49] FEMA P695, "Quantification of Building Seismic Performance Factors", Federal Emergency Management Agency, 2009.

[50] ASCE 7, "Minimum Design Loads for Buildings and Other Structures", American Society of Civil Engineers, 2010.

[51] G. W. Housner, "Limit design of structures to resist earthquakes", In: Proceedings of First World Conference on Earthquake Engineering, vol. 5, pp. 1-12, 1956

[52] H. Akiyama, Earthquake-resistant limit-state design for buildings, University of Tokyo Press, Tokyo, 1985.

[53] F. López Almansa, U. Yazgan, and A. Benavent Climent, "Design energy input spectra for high seismicity regions based on Turkish registers", Bulletin of Earthquake Engineering, vol. 11, no. 4, pp. 885-912, 2013. doi 10.1007/s10518-012-9415-2.

(C) Palazzo et al.; Licensee Bentham Open.

This is an open access article licensed under the terms of the Creative Commons Attribution Non-Commercial License (http://creativecommons.org/licenses/ by-nc/3.0/) which permits unrestricted, non-commercial use, distribution and reproduction in any medium, provided the work is properly cited. 